\title{
REVITALISASI PERAN PESANTREN DI ERA 4.0
}

\author{
Mohammad Darwis \\ Institut Agama Islam Syarifuddin Lumajang \\ Email: mohammad.darwis7o@gmail.com
}

\begin{abstract}
This paper discusses the revitalization of the role of pesantren in the 4.0 era by critically examining the process of change and development of pesantren due to the industrial revolution 4.0. This study begins with the development of an era that is entering the 4.0 revolution era, where all life is done digitally, starting from the digital economy, artificial intelligence, big data, and robotic. This will further change the established pesantren curriculum system, and in this era the world of education will experience its own challenges to adjust it including the education found in pesantren. Therefore pesantren must be able to make a change by revitalizing the role of pesantren so that later the existence of pesantren in the community can continue to be maintained, and pesantren graduates will be able to compete when in the community.
\end{abstract}

Keywords: Islamic Education, Islamic Boarding Schools, Era 4.0

\section{PENDAHULUAN}

Pesantren merupakan salah satu lembaga pendidikan Islam tradisional yang tumbuh dan berkembang di tengah-tengah masyarakat. Pesanten juga memiliki tujuan untuk ikut mencerdaskan bangsa Indonesia, yang mana dari dulu hingga sekarang pesantren selalu memberikan kontribusi yang cukup besar dalam kegiatan pendidikan di Indonesia. Selain itu, pesantren merupakan lembaga pendidikan Islam tradisional yang bertujuan untuk mengajari dan mengamalkan ajaran-ajaran Islam yang menekankan pada pentingnya moral agama dalam berkehidupan di masyarakat. ${ }^{1}$ Sistem pembelajarannya pun dilaksanakan secara klasikal, dimana kiai mengajarkan pendidikan agama Islam melalui pengajian kitab-kitab yang ditulis dalam bahasa Arab oleh ulama-ulama

\footnotetext{
${ }^{1}$ Samsul Nizar, Sejarah Sosial \& Dinamika Intelektual Pendidikan Islam di Nusantara (Jakarta: Kencana, 2013), 85.
} 
abad pertengahan dan para santri pun harus menetap dan tinggal di pesantren tersebut. $^{2}$

Selain pesantren, ada beberapa lembaga pendidikan yang mengajarkan ajaran Islam di Indonesia, yaitu Surau (Padang), Meunasah, Masjid, Rangkang, dan Dayah (Aceh). Beberapa lembaga pendidikan Islam ini ikut mewarnai sejarah pendidikan Islam di Indonesia. ${ }^{3}$ Namun dari beberapa lembaga pendidikan Islam tersebut, pesantren lah yang mampu bertahan dan tidak tergusur oleh perubahan zaman, sedangkan pendidikan Islam lainnya hanya tersisa artefak dan fisiologi ajarannya. Lembaga pendidikan pesantren mampu bertahan dan mengalami perubahan sesuai dengan perkembangan zaman. Bahkan saat ini pesantren menjelma menjadi lembaga pendidikan Islam yang mampu bersaing dengan lembaga pendidikan umum. Hal ini terbukti dengan adanya lembaga pendidikan formal di pesantren seperti SD/ MI, SMP/ MTs, SMA/MA/ SMK/MAK, dan juga perguruan tinggi. ${ }^{4}$

Pergerakan arus globalisasi yang semakin hari semakin cepat berkembang, mengharuskan pesantren untuk melakukan perubahan dan perkembangan agar bisa mempertahankan eksistensinya di masyarakat. Ditambah lagi dengan kemunculan istilah revolusi industri 4.0 yang ditandai dengan semakin sentralnya peran teknologi dalam kehidupan masyarakat. Oleh karenanya pesantren harus mampu menyesuaikan diri pada era 4.0 ini, dimana pada era ini semua aktivitas yang dilakukan berbasis digital, mulai dari digital economy, artificial intelligence, big data, dan robotic. ${ }^{5}$

Sebagaimana ketika mengahadapi beberapa perubahan zaman yang telah dulu, maka pesantren juga harus mampu menyesuaikan diri di era 4.0 ini. Pesantren harus bisa mengambil peran dalam pengambilan kebijakan

\footnotetext{
${ }^{2}$ Muhammad Abdul Manam, Daya Tahan dan Eksistensi Pesantren di Era 4.0, Jurnal JPII Vol. 3 No. 2 April 2019, 302.

${ }^{3}$ Hariadi, Evolusi Pesantren: Studi Kepemimpinan Kiai Berbasis Orientasi ESQ (Yogyakarta: LkiS, 2015), 35.

${ }^{4}$ Muhammad Abdul Manam, Daya Tahan, 302.

5 Rahmat, Pendidikan Agama Islam Berwawasan Interdisipliner Sebagai Corak dan Solusi Pendidikan Agama Islam Era 4.0, Jurnal Tribakti Vol. 30 No. 2 Juli 2019, 350.
} 
menentukkan kurikulum yang tepat. Hal ini dikarenakan agar nantinya lulusanlulusan pesantren bisa bersaing dengan lulusan-lulusan pendidikan umum lainnya dan juga agar eksistensi pesantren di mata masyarakat bisa terus terjaga.

\section{PEMBAHASAN}

\section{Pesantren}

Secara etimologi pesantren berasal dari kata "santri" yang diberi awalan "pe” dan akhiran "an” yaitu pe-santri-an yang berarti tempat bagi para santri. Asal kata santri itu sendiri terdiri dari gabungan kata "sant" yang berarti manusia baik-baik dan kata "tra" yang berarti suka menolong. Jadi Pesantren adalah tempat mengajarkan ilmu pengetahuan kepada manusia yang baik. Menurut Gibb dalam buku Hariadi, pesantren is javanese "santri-place", seminary for student of teology (santri) on the island of Java and Madura (pesantren adalah tempat santri Jawa, seminari bagi santri di pulau Jawa dan Madura). ${ }^{6}$ Pesantren merupakan istilah yang dipakai di Jawa dan Madura untuk lembaga pendidikan yang mengajarkan ajaran Islam, sedangkan istilah lainnya adalah surau, menuasah, dayah, dan rangkang. ${ }^{7}$

Adapun secara terminologis, Steenbrink menjelaskan bahwa pesantren berasal dari India. Sebelum Islam masuk ke Indonesia, sistem yang dipakai oleh pesantren untuk mengajarkan agama Islam, sudah dipakai dan dipraktekkan untuk mengajarkan ajaran Hindu di Jawa. Namun setelah Islam masuk ke Indonesia, sistem tersebut diadopsi oleh Islam yang kemudian muncul istilah pesantren. Sebenarnya istilah pesantren sama halnya dengan istilah mengaji, langgar, atau surau yang terdapat di Minangkabau. ${ }^{8}$ Jadi pesantren bisa didefinisikan sebagai lembaga pendidikan Islam yang memiliki kekhasan tersendiri dan berbeda dengan lembaga pendidikan pada umumnya. Dimana

\footnotetext{
${ }^{6}$ Hariadi, Evolusi Pesantren, 9.

${ }^{7}$ Ibid, 35.

${ }^{8}$ Samsul Nizar, Sejarah Sosial, 87.
} 
pesantren mengajarkan ajaran-ajaran Islam kepada para peserta didiknya yang biasa disebut santri, sosok kiai sebagai figur sentral, masjid sebagai pusat pembelajaran dan santri yang mengaji harus menetap dan tinggal di pesantren. ${ }^{9}$

\section{Unsur-Unsur Pesantren}

Pesantren merupakan lembaga pendidikan yang menngajarkan pendidikan agama Islam. Lembaga pendidikan Islam ini juga memiliki beberapa unsur agar bisa disebut sebagai pesantren. Adapun beberapa unsur tersebut adalah:

1. Kiai

Kata "kiai" berasal dari bahasa jawa kuno "kia-kia" yang artinya orang yang dihormati. Secara terminologis kiai adalah pendiri dan pemimpin pesantren yang membaktikan hidupnya untuk agama Allah dengan cara menyebarluaskan dan mendalami ajaran-ajaran Islam. Keberadaan kiai sebagai pemimpin pesantren, ditinjau dari peran dan fungsinya dapat dipandang sebagai fenomena kepemimpinan yang unik. Hal ini karena selain memimpin lembaga pendidikan Islam, kiai juga sebagai pembina, pendidik umat, dan pemimpin masyarakat. ${ }^{10}$

Menurut Hariadi dalam bukunya menjelaskan bahwa kiai merupakan unsur pesantren terpenting sekaligus tokoh sentral dan esensial. Hal ini dikarenakan kiai adalah perintis, pendiri, pengelola, pengasuh, pemimpin dan pemilik tunggal sebuah pesantren. Sehingga maju dan mundurnya sebuah pesantren tergantung pada sosok kiai tersebut, terutama keahlian, kedalaman ilmu agama, wibawa, dan karismatrik seorang kiai serta keterampilannya dalam memimpin pesantren. ${ }^{11}$ Sebagaimana yang dijelaskan oleh Karel A. Steenbrink, dimana

\footnotetext{
${ }^{9}$ Erfan Gazali, Pesantren diantara Generasi Alfa dan Tantangan Dunia Pendidikan Era Revolusi Industri 4.0, Jurnal OASIS Vol. 2 No. 2 Februari 2018, 97.

${ }_{10}$ Maskuri Bakri dan Dyah Werdaningsih, Membumikan Nilai Karakter Berbasis Pesantren (Yogyakarta: Nirmana Media, 2011), 20.

${ }^{11}$ Hariadi, Evolusi Pesantren, 18.
} 
untuk menjadi seorang kiai dapat ditentukan oleh beberapa faktor, antara lain: pengetahuan, keturunan, murid-muridnya, dan cara yang digunakan dalam mengabdikan hidupnya kepada masyarakat. Karisma dan wibawa yang terdapat dalam diri seorang kiai adalah akibat dari kedalaman ilmu yang dimilikinya, akhlak, kepribadian yang mulia serta keshalehannya. Sehingga kiai bisa menjadi teladan bagi para santrinya dan bahkan teladan bagi masyarakat. ${ }^{12}$

2. Santri

Dalam dunia pendidikan Islam, terdapat dua istilah bagi peserta didik yaitu murid dan santri. Kata santri berasal dari bahasa India yaitu shastri yang berarti orang yang ahli dalam kitab suci agama Hindu. Zaini Muchtarom mengupas kata shastri lebih jauh dengan mengatakan "shastri berasal dari kata shastra yang berarti scipture atau religious or a scientific treatise yaitu karangan agama atau uraian ilmiah". ${ }^{13}$ Namun menurut masyarakat, santri adalah anak yang belajar mengaji atau mereka yang belajar kepada Kyai di pondok pesantren. ${ }^{14}$

Zamakhsyari Dhofier mengelompokkan santri menjadi 2 kelompok yaitu santri mukim dan santri kalong. Santri mukim adalah santri atau murid yang berasal dari daerah jauh yang belajar dan menetap di pesantren. Sedangkan santri kalong adalah santri atau murid yang belajar di pesantren yang tidak menetap di pesantren karena tempat tinggalnya berada di sekitar pesantren. ${ }^{15}$

3. Masjid

Masjid merupakan unsur yang tidak dapat dipisahkan dari pesantren karena dianggap tempat yang paling tepat untuk mengajarkan ilmu agama

\footnotetext{
12 Samsul Nizar, Sejarah Sosial, 131.

${ }^{13}$ Maskuri Bakri dan Dyah Werdaningsih, Membumikan Nilai, 20.

${ }^{14}$ Samsul Nizar, Sejarah Sosial, 131.

15 Zamakhsyari Dhofier, Tradisi Pesantren: Studi Pandangan Hidup Kiai dan Visinya Mengenai Masa Depan Indonesia (Jakarta: LP3ES, 2011), 89.
} 
kepada para santri. Terlebih ketika ilmu yang diajarakan berupa hal-hal yang berhubungan dengan ibadah seperti praktik sholat lima waktu, praktik khutbah dan sholat Jum'at, dan ibadah-ibadah yang lain. Selain itu masjid juga bisa dijadikan sebagai tempat untuk mengkaji kitab-kitab kuning. ${ }^{16}$ Fungsi lain dari masjid biasanya adalah sebagai tempat bagi santri untuk menghafal dan mengulang pelajaran yang sudah dipelajari di kelas.

Keberadaan masjid sebagai tempat pembelajaran sebenarnya sudah berlangsung sejak masa Rasulullah SAW., kemudian dilanjutkan pada masa khulafa ar-rasyidin, dinasti Umaiyyah, dinasti Abbasyiyyah, dan dilestarikan oleh para ulama hingga berlangsung sampai sekarang. ${ }^{17}$

4. Pengajian Kitab Kuning

Kitab kuning adalah sebuah sebutan pada kitab-kitab rujukan keagamaan yang umumnya interpretasi dan hasil ijtihad para ulama atas segenap ayat-ayat al-Qur'an dan hadits-hadits. ${ }^{18}$ Pada masa lalu, pengajaran kitab kuning (terutama karangan ulama-ulama yang menganut madzhab syafi'i) merupakan satu-satunya pengajaran kurikulum yang ada di pesantren. Hal ini bertujuan untuk mendidik para santrinya menjadi calon-calon ulama. Namun ada beberapa santri yang hanya berniat untuk menambah pengalaman belajar, biasanya santri yang seperti ini hanya berada di pesantren ketika bulan Ramadhan saja. ${ }^{19}$

Dalam tradisi pesantren, pengajaran kitab-kitab kuning ini dilakukan dengan berbagai metode yaitu: metode sorogan, metode wetonan dan bondongan, dan metode musyawarah. Pertama metode sorogan, metode ini merupakan metode belajar kitab kuning dimana kiai hanya mengajari satu orang santri atau sekelompok kecil santri, apabila santri tersebut sudah menguasai materi maka akan ditambah ke materi berikutnya dan

\footnotetext{
${ }^{16}$ Ibid, 85.

${ }^{17}$ Hariadi, Evolusi Pesantren, 22.

18 Maskuri Bakri dan Dyah Werdaningsih, Membumikan Nilai, 21.

${ }^{19}$ Zamakhsyari Dhofier, Tradisi Pesantren, 86.
} 
apabila ada santri yang belum menguasai maka santri tersebut harus menetap pada bab yang belum dikuasai tersebut. Kedua metode wetonan dan bandongan, metode ini merupakan metode belajar kitab kuning dengan model ceramah. Biasanya pembelajaran ini digunakan untuk kelas besar. Dan yang ketiga adalah metode musyawarah, dimana dalam hal ini santri lebih aktif membahas materi kitab kuning yang telah dipelajarinya, dan kiai hanya memberi bimbingan seperlunya. ${ }^{20}$

5. Pondok

Dalam tradisi pesantren, pondok merupakan bangunan yang digunakan sebagai tempat tinggal santri untuk menetap. Umumnya bangunan pondok ini dikelilingi oleh pagar pembatas untuk menjaga para santrinya. ${ }^{21}$ Istilah pondok sendiri diambil dari bahasa Arab funduq yang berarti asrama atau penginapan. Dengan demikian, sebuah pesantren haruslah memiliki sebuah pondok sebagai tempat tinggal santri. Di tempat ini pula, komunikasi intensif terjadi antara kiai dan santri. Komunikasi yang intensif di pesantren merupakan sebuah kondisi yang kondusif dalam rangka interaksi-endukatif. ${ }^{22}$

\section{Perubahan dan Kesinambungan Tradisi Pesantren Sebagai Bentuk \\ Reaktualisasi Peran Pesantren di Era 4.0}

Pesantren merupakan lembaga pendidikan dan pusat penyebaran agama Islam. Pesantren hadir dan berkembang mulai masa-masa permulaan Islam masuk ke Indonesia. ${ }^{23}$ Dahulu pelajaran dan kurikulum yang digunakan pesantren pun masih tradisional, yakni hanya sebatas mengajarkan ilmu-ilmu agama Islam saja tanpa terdapat materi pelajaran umum. Ilmu-ilmu yang diajarkan pun seperti: ilmu tafsir, fiqih, ushul figh, tauhid, tasawuf, nahwu, dan

\footnotetext{
${ }^{20}$ Samsul Nizar, Sejarah Sosial, 93-94.

${ }^{21}$ Ibid, 92.

${ }^{22}$ Hariadi, Evolusi Pesantren, 26.

${ }^{23}$ Bashori, Modernisasi Lembaga Pendidikan Pesantren, Jurnal Ilmu Sosial Mamangan Vol. 6 No. 1 Januari-Juni 2017, 50.
} 
sharaf. Semua pelajaran tersebut merujuk pada kitab-kitab yang dikarang oleh ulama-ulama terdahulu (ulama abad pertengahan). Lembaga pendidikan yang terdapat di pesantren hanya sebatas lembaga pendidikan non formal yang bersistem klasikal, dimana kenaikan tingkat seorang santri ditandai dengan khatamnya kitab yang dipelajari oleh santri tersebut. ${ }^{24}$

Namun seiring dengan perkembangan zaman, pesantren juga ikut berkembang secara signifikan. Hal ini dikarenakan agar eksistensi pesantren di masyarakat selalu terjaga. Pesantren-pesantren pada zaman sekarang mulai mendirikan lembaga-lembaga formal seperti MI/ SD, MTs/SMP, MA/SMA/MAK/ SMK, bahkan ada pesantren yang memiliki perguruan tinggi. Pelajaran dan kurikulum yang digunakan juga menyamakan dengan lembaga pendidikan pada umumnya. Dan di era revolusi indistri 4.0 ini, pesantren juga harus mengalami perubahan, salah satunya di bidang kurikulumnya. Pesantren harus bisa menyesuaikan kurikulum pendidikan karena di era 4.0 ini masyarakat akan hidup dengan serba digital. Hal ini dimaksudkan agar lulusan pesantren juga bisa bersaing dengan lulusan-lulusan dari lembaga pendidikan umum lainnya.

Sebagaimana pernyataan Kiai Syamsuri yang dikutip dalam buku Zamakhsyari Dhofier menyebutkan bahwa perubahan dan perkembangan yang ada di pesantren bukan semata-mata menghapus semua tradisi yang sudah ada, namun untuk menyelaraskan dengan yang dibutuhkan oleh masyarakat. Jadi pendidikan yang terdapat di pesantren, selain mengajarkan ilmu agama juga mengajarkan ilmu umum, sehingga nantinya mampu meneruskan pendidikan santri ke universitas-universitas negeri. Namun selain itu, para santri juga dididik untuk mampu membaca kitab-kitab kuning dan menyebarkannya dimasyarakat. Sehingga ketika mereka kelak bisa meneruskan ke tingkat yang lebih tinggi dan bisa memegang jabatan-jabatan penting seperti halnya menjadi pemimpin,

\footnotetext{
${ }^{24}$ Samsul Nizar, Sejarah Sosial, 116-117.
} 
maka mereka akan menjadi pemimpin yang berpegang pada ajaran-ajaran Islam dan melaksanakan kepemimpinannya sesuai dengan cara-cara Islam. ${ }^{25}$

Mungkin sekilas perubahan dan perkembangan pesantren ke arah yang lebih modern membuat pesantren melupakan tugas utamanya untuk membentuk calon-calon ulama. Namun ketika dilihat lebih dalam lagi, perubahan itu sama sekali tidak menghapus tujuan awal dari pesantren ini. Sebagaimana yang diuraikan oleh Prof. Gibb yang mengatakan bahwa dalam setiap kebudayaan yang telah mapan (termasuk kebudayaan Islam di Indonesia - pesantren) akan selalu terdapat kecenderungan sikap atau orientasi duniawiyah, baik itu secara terbuka maupun terpendam. Namun pengertian dari sifat duniawiyah sendiri telah diartikan secara luas oleh para ulama. Sebagaimana yang disebutkan oleh kiai Syamsuri yang beliau ambil dari kitab ta'lim al-muta'allim:

"banyak perbutaan manusia yang tampaknya bertalian dengan urusanurusan duniawi, tetapi karena niatnya yang bagus, maka perbuatan tersebut diterima oleh Allah sebagai amal akhirat. Tetapi banyak pula perbuatan manusia yang tampaknya bertalian dengan urusan-urusan akhirat, tetapi karena disertai dengan niat yang buruk, maka Allah tidak memberinya pahala yang sama".

Pernyataan-pernyataan tersebut bisa dijadikan pedoman agar pesantren melakukan perubahan dan perkembangan sesuai dengan perubahan zaman yang ada. Hal ini agar lulusan pesantren bisa bersaing dan iku andil dalam segala urusan duniawi terlebih di era revolusi 4.0 ini, sehingga nantinya mereka menjadi penguasa yang memegang teguh ajaran-ajaran Islam.

\section{PENUTUP}

${ }^{25}$ Zamakhsyari Dhofier, Tradisi Pesantren, 200. 
Pesantren merupakan lembaga pendidikan Islam yang memiliki kekhasan tersendiri dan berbeda dengan lembaga pendidikan pada umumnya. Dimana pesantren mengajarkan ajaran-ajaran Islam kepada para peserta didiknya yang biasa disebut santri, sosok kiai sebagai figur sentral, masjid sebagai pusat pembelajaran dan santri yang mengaji harus menetap dan tinggal di pesantren. Dahulu pelajaran dan kurikulum yang digunakan pesantren pun masih tradisional, namun seiring dengan perubahan zaman (seperti halnya saat ini di era 4.0), pesantren mengalami perubahan dan perkembangan yang sangat signifikan. Hal ini dilakukan agar lulusan pesantren bisa bersaingan dengan lulusan lembaga pendidikan umum lainnya.

\section{REFERENSI}

Bakri, Maskuri dan Dyah Werdaningsih. 2011. Membumikan Nilai Karakter Berbasis Pesantren. Yogyakarta: Nirmana Media.

Bashori. Modernisasi Lembaga Pendidikan Pesantren, Jurnal Ilmu Sosial Mamangan Vol. 6 No. 1 Januari-Juni 2017, 47-60.

Dhofier, Zamakhsyari. 2011. Tradisi Pesantren: Studi Pandangan Hidup Kiai dan Visinya Mengenai Masa Depan Indonesia. Jakarta: LP3ES.

Gazali, Erfan. Pesantren diantara Generasi Alfa dan Tantangan Dunia Pendidikan Era Revolusi Industri 4.0, Jurnal OASIS Vol. 2 No. 2 Februari 2018, 94-109.

Hariadi. 2015. Evolusi Pesantren: Studi Kepemimpinan Kiai Berbasis Orientasi ESQ. Yogyakarta: LkiS.

Manam, Muhammad Abdul. Daya Tahan dan Eksistensi Pesantren di Era 4.0, Jurnal JPII Vol. 3 No. 2 April 2019, 301-313.

Nizar, Samsul. 2013. Sejarah Sosial \& Dinamika Intelektual Pendidikan Islam di Nusantara. Jakarta: Kencana.

Rahmat. Pendidikan Agama Islam Berwawasan Interdisipliner Sebagai Corak dan Solusi Pendidikan Agama Islam Era 4.0, Jurnal Tribakti Vol. 30 No. 2 Juli 2019, 349-361. 